\title{
Meta-analysis of association between TCF7L2 polymorphism rs7903146 and type 2 diabetes mellitus
}

\author{
Weiyue Ding ${ }^{1 \dagger}, \mathrm{Li} \mathrm{Xu}^{1 *+} \mathbb{D}$, Lejun Zhang ${ }^{2}$, Zhijie Han ${ }^{3}$, Qinghua Jiang ${ }^{3}$, Zhe Wang ${ }^{4}$ and Shuilin Jin ${ }^{*}$
}

\begin{abstract}
Background: Large scale association studies have found a significant association between type 2 diabetes mellitus (T2DM) and transcription factor 7-like 2 (TCF7L2) polymorphism rs7903146. However, the quality of data varies greatly, as the studies report inconsistent results in different populations. Hence, we perform this meta-analysis to give a more convincing result.

Methods: The articles, published from January 1st, 2000 to April 1st, 2017, were identified by searching in PubMed and Google Scholar. A total of 56628 participants (34232 cases and 22396 controls) were included in the meta-analysis. A total of 28 studies were divided into 4 subgroups: Caucasian (10 studies), East Asian (5 studies), South Asian (5 studies) and Others (8 studies). All the data analyses were analyzed by the R package meta.

Results: The significant association was observed by using the dominant model $(\mathrm{OR}=1.41, \mathrm{Cl}=1.36-1.47, p<0.0001)$, recessive model $(\mathrm{OR}=1.58, \mathrm{Cl}=1.48-1.69, p<0.0001)$, additive model( $C T$ vs $C C)(\mathrm{OR}=1.34, \mathrm{Cl}=1.28-1.39, p<0.0001)$, additive model(TT vs CC) $(\mathrm{OR}=1.81, \mathrm{Cl}=1.69-1.94, p<0.0001)$ and allele model $(\mathrm{OR}=1.35, \mathrm{Cl}=1.31-1.39, p<0.0001)$.
\end{abstract}

Conclusion: The meta-analysis suggested that rs 7903146 was significantly associated with T2DM in Caucasian, East Asian, South Asian and other ethnicities.

Keywords: T2DM, Polymorphism, rs7903146, Meta-analysis

\section{Background}

Diabetes is one of the largest global health emergencies in the twenty-first century. According to the International Diabetes Federation (IDF) [1], 46.5\% of the adults with diabetes are undiagnosed, and 1 in 11 adults, about 415 million people, have diabetes. Every $6 \mathrm{~s}$ a person dies of diabetes (5.0 million deaths per year). By 2040, 1 in 10 adults, approximately 642 million people, will have diabetes. Notably, $12 \%$ of the global health expenditure, up to $\$ 673$ billion, is dedicated to diabetes treatments, and the related take up most of the total expenditure.

The most prevalent form of diabetes is type 2 diabetes mellitus (T2DM), and in the developed countries up to

\footnotetext{
*Correspondence: xuli@hrbeu.edu.cn; jins|@hit.edu.cn

${ }^{\dagger}$ Equal contributors

${ }^{1}$ College of Computer Science and Technology, Harbin Engineering University,

No.145 Nantong Street, Nangang District, 150001 Harbin, China

${ }^{5}$ Department of Mathematics, Harbin Institute of Technology, No.92, Xidazhi

Street, Nangang District, 150001 Harbin, China

Full list of author information is available at the end of the article
}

$91 \%$ of the adults, who are being troubled by the diabetes, have T2DM. Excess body weight, physical inactivity, poor nutrition, genetics, family history of diabetes, past history of gestational diabetes and older age are risk factors that increase the rate of T2DM. Besides, T2DM is a complex disease, and and the function of the glycosylation plays a significant role [2, 3].

The SNP rs7903146(C/T) is a common variant in the gene TCF7L2, and allele $\mathrm{T}$ is the risk allele related to T2DM. The gene TCF7L2 is a transcription factor involved in the Wnt signaling pathway, and acts as a critical component of Wht signalling and action [4-6]. The TCF7L2 gene product, a high mobility group box-containing transcription factor previously implicated in blood glucose homeostasis, is considered to act through the regulation of proglucagon gene expression in enteroendocrine cells via the Wnt signaling pathway [7]. In human islets, TCF7L2 expression associates positively with insulin gene expression $[8,9]$. 
To address the genetic variations of T2DM, many scholars devoted themselves to the related research [10-16]. The common Pro12Ala polymorphism rs 1801282 in PPAR $\gamma$, the E23K variant rs5219 in KCNJ11, the polymorphism of the 5-HT2C receptor rs3813929 and the VKORC1 polymorphism rs9923231 were found to be associated with T2DM [17-20]. In 2006, Grant SF, et al. [7] confirmed a strongly significant association between susceptibility related to T2DM and common variants in transcription factor 7-like 2 (TCF7L2) in Icelandic subjects, and the result was the same with case-control method in Danish cohort and U.S. cohort. In 2006, Cauchi et al. [21] reported that the T-allele of the single nucleotide polymorphism (SNP) rs7903146 increased the risk of T2DM in the French population with 2367 cases and 2499 controls.The same results were shown by Horikoshi, Yu and Barra in case of the Japanese population, African American population and Brasilia [22-24]. However, Zheng et al. [25] found no association between rs7903146 and T2DM in the Chinese population.
The quality of the data varies greatly, is one of the reasons that the studies report inconsistent results, and the small sample size is another reason. The statistical efficiency can be improved after combining some samples together. The collected data in the control group was tested by the Hardy-Weinberg Equilibrium (HWE) in view of the quality of data. Therefore, we conducted a metaanalysis of published studies involving rs7903146 and T2DM to achieve a more comprehensive result. Finally, a total of 28 studies from 26 single studies [4, 22-46] were collected to reevaluate the association between rs7903146 and T2DM.

\section{Methods}

\section{Search strategy}

The articles, published from January 1st, 2000 to April 1st, 2017, were identified by searching the keywords "rs7903146" and "type 2 diabetes mellitus" in PubMed and Google Scholar. The selected articles were written in English.

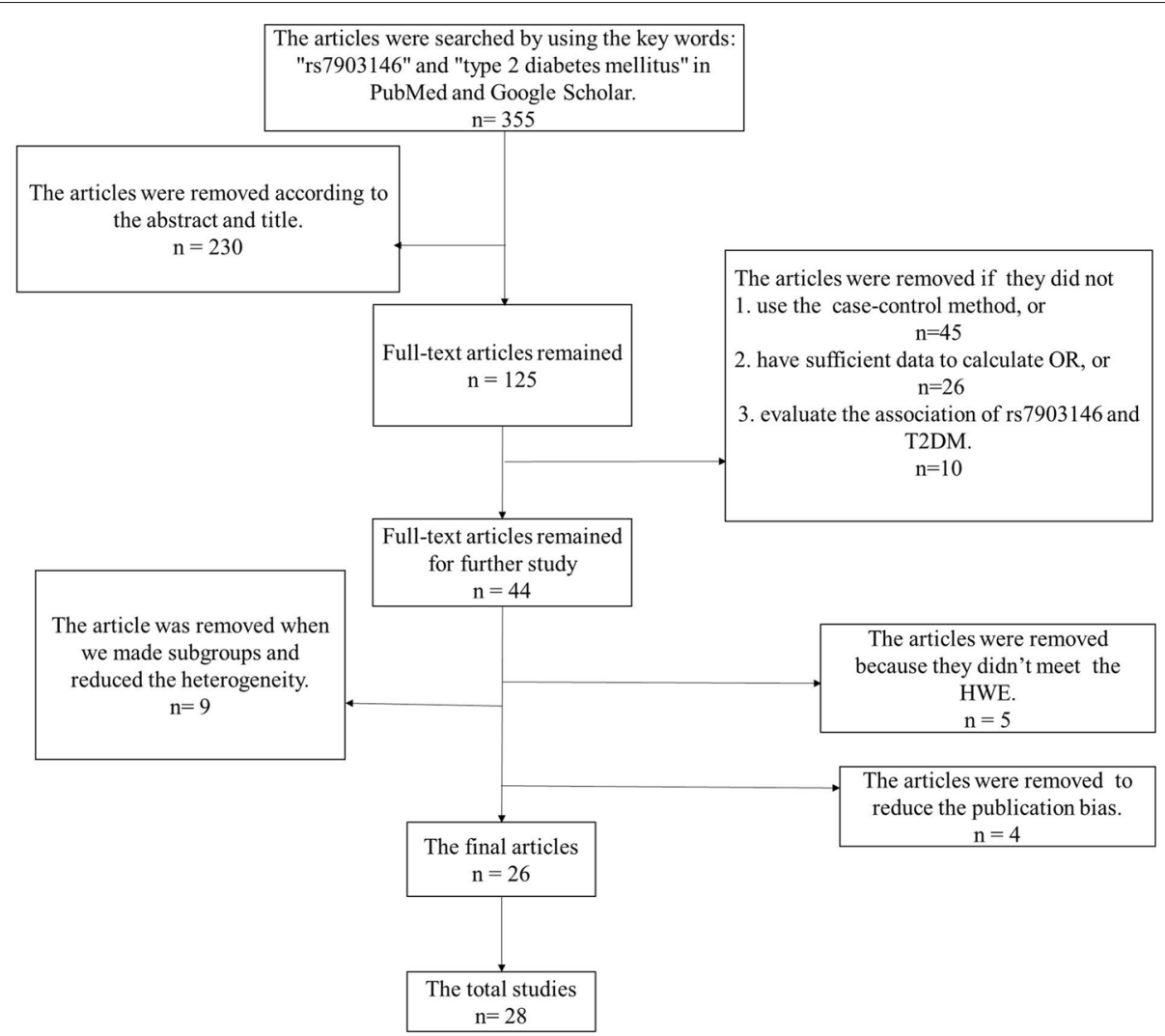

Fig. 1 The flow chart of collecting articles for analyzing the association. And a total of 355 articles were identified by the search strategy. Firstly, a total of 230 articles were removed according to the title and abstract, and 45 articles were removed as the studies did not use case-control method, and 26 articles were removed as the studies did not have sufficient data to calculate OR, and 10 articles were excluded as they did not evaluate the association between rs 7903146 and T2DM. After that 44 articles remained. Then, 5 articles were excluded as the control groups didn't meet the Hardy-Weinberg Equilibrium (HWE), 9 articles were excluded when we made subgroup analyses and reduced the heterogeneity, and 4 articles were excluded as some LADA or type 1 diabetes patients were included in the case groups. Finally 28 studies from 26 articles were left 


\section{Study selection criteria}

We selected studies according to the following criteria: (1) The study was designed based on the case-control method. (2) The study evaluated the association between rs7903146 and T2DM. (3) The number of genotypes in case-controls groups was provided for calculating Odds Ratios (ORs). (4) The control group meets HWE. Besides, the $p$ value of HWE was calculated by R program HWE version 1.2 [47]. If $p<0.05$, the article was preserved, otherwise the article was removed.

\section{Data extraction}

We extracted the following information from each study: (1) the first author of each article; (2) the publication year of each article; (3) the population of the study; (4) the ethnicity of individuals in each study; (5) the number of the rs7903146 genotypes both in cases and controls; (6) $p$ value of HWE in the control group. We used R package meta to analyze the data. We also referred to some other methods [48-51] to conduct the meta-analysis.

\section{Choice of genetic model}

The rs7903146 has two alleles: $\mathrm{C}$ and T. We analyzed the association between rs7903146 and T2DM by using the dominant model $(\mathrm{TT}+\mathrm{CT}$ versus $\mathrm{CC})$, recessive model ( $\mathrm{TT}$ versus $\mathrm{CC}+\mathrm{CT}$ ), additive model $(\mathrm{CT}$ versus $\mathrm{CC}$ ), additive model(TT versus CC) and allele model (T versus $\mathrm{C}$ ), respectively [52].

Table 1 The primary characteristics of the 28 studies

\begin{tabular}{|c|c|c|c|c|c|c|c|c|c|c|}
\hline \multirow[b]{2}{*}{ Study } & \multirow[b]{2}{*}{ Year } & \multirow[b]{2}{*}{ Population } & \multirow[b]{2}{*}{ Ethnicity } & \multicolumn{3}{|c|}{ T2DM } & \multicolumn{3}{|c|}{ Control } & \multirow[b]{2}{*}{ HWE } \\
\hline & & & & $\mathrm{CC}$ & CT & $\pi$ & CC & $\mathrm{CT}$ & $\pi$ & \\
\hline Ezzidi et al. & 2009 & Arabic Tunisian & Arab & 250 & 396 & 217 & 181 & 235 & 95 & 0.227155 \\
\hline Saadi et al. & 2008 & Arab & Arab & 30 & 54 & 11 & 71 & 94 & 23 & 0.388992 \\
\hline Humphries et al. & 2006 & Afro-Caribbean & Black African & 141 & 136 & 30 & 161 & 124 & 26 & 0.75859 \\
\hline Yu et al. & 2009 & African American & Black African & 255 & 212 & 48 & 1156 & 921 & 165 & 0.31807 \\
\hline Danquah et al. & 2013 & Ghanaian & Black African & 273 & 323 & 78 & 182 & 165 & 28 & 0.257132 \\
\hline Yu et al. & 2009 & USA Caucasian & Caucasian & 430 & 392 & 101 & 4295 & 3391 & 693 & 0.515248 \\
\hline Groves et al. & 2006 & English & Caucasian & 771 & 960 & 270 & 1175 & 1084 & 217 & 0.944175 \\
\hline Humphries et al. & 2006 & European & Caucasian & 601 & 665 & 193 & 1295 & 1001 & 197 & 0.854011 \\
\hline Cauchi et al. & 2006 & Austrian & Caucasian & 200 & 208 & 78 & 555 & 432 & 88 & 0.759981 \\
\hline Dahlgren et al. & 2007 & Swedish & Caucasian & 67 & 83 & 18 & 496 & 327 & 62 & 0.421344 \\
\hline Mayans et al. & 2007 & Swedish & Caucasian & 452 & 318 & 54 & 532 & 253 & 35 & 0.480907 \\
\hline Van et al. & 2007 & Dutch & Caucasian & 203 & 221 & 72 & 459 & 365 & 83 & 0.396927 \\
\hline Kimber et al. & 2007 & English & Caucasian & 1405 & 1459 & 361 & 1714 & 1329 & 248 & 0.662991 \\
\hline De Silva et al. & 2007 & English & Caucasian & 420 & 507 & 161 & 1032 & 887 & 180 & 0.58617 \\
\hline Vcelak et al. & 2012 & Czech & Caucasian & 148 & 156 & 43 & 205 & 147 & 24 & 0.730572 \\
\hline Hayashi et al. & 2007 & Japanese & East Asian & 1450 & 165 & 4 & 980 & 85 & 2 & 0.91209 \\
\hline Horikoshi et al. & 2007 & Japanese & East Asian & 165 & 22 & 2 & 251 & 21 & 0 & 0.507848 \\
\hline Kazuaki et al. & 2008 & Japanese & East Asian & 1921 & 228 & 5 & 1696 & 137 & 1 & 0.29539 \\
\hline Yasuharu et al. & 2009 & Japanese & East Asian & 434 & 45 & 2 & 372 & 26 & 0 & 0.50056 \\
\hline Zheng et al. & 2011 & Chinese & East Asian & 202 & 24 & 1 & 139 & 13 & 0 & 0.581813 \\
\hline Marquezine et al. & 2007 & Brazilian & Brazilian & 45 & 54 & 13 & 564 & 603 & 128 & 0.070107 \\
\hline Barra et al. & 2013 & Brazilian & Brazilian & 55 & 49 & 6 & 58 & 40 & 11 & 0.304112 \\
\hline Assmann et al. & 2014 & Brazilian & Brazilian & 382 & 415 & 156 & 261 & 215 & 59 & 0.147418 \\
\hline Bodhini et al. & 2007 & Asian Indian & South Asian & 462 & 455 & 114 & 555 & 391 & 92 & 0.531352 \\
\hline Chandak et al. & 2007 & Indian & South Asian & 391 & 423 & 141 & 205 & 160 & 34 & 0.726021 \\
\hline Rees et al. & 2008 & UK South Asian & South Asian & 352 & 360 & 116 & 222 & 166 & 44 & 0.12238 \\
\hline Gupta et al. & 2010 & Indian & South Asian & 55 & 96 & 44 & 62 & 78 & 21 & 0.64658 \\
\hline Hussain et al. & 2014 & Indian & South Asian & 25 & 36 & 7 & 43 & 35 & 4 & 0.349985 \\
\hline
\end{tabular}

A total of 56628 participants (34,232 cases and 22,396 controls) of 28 studies from 26 articles were included in the study. The name of the first author, the publication year of, the population of the study, the ethnicity of the study, the genotypes of the case-control group and the $P$ value of HWE. If the $p$ value of HWE in control group met the selection criteria $(P>0.05)$, it would be preserved, otherwise the data would be removed 
Table 2 The result of the heterogeneity in subgroup analyses

\begin{tabular}{|c|c|c|c|c|c|c|c|c|c|c|}
\hline \multirow{2}{*}{ Subgroup } & \multicolumn{2}{|c|}{ Dominant } & \multicolumn{2}{|c|}{ Recessive } & \multicolumn{2}{|c|}{ Additive(CT vs CC) } & \multicolumn{2}{|l|}{ Allele } & \multicolumn{2}{|c|}{ Additive(TT vs CC) } \\
\hline & $R^{2}$ & $P$ & $1^{2}$ & $P$ & $P^{2}$ & $P$ & $1^{2}$ & $P$ & $\mathrm{P}^{2}$ & $P$ \\
\hline Caucasian & $28.00 \%$ & 0.18 & $0.00 \%$ & 0.51 & $9.00 \%$ & 0.36 & $38.00 \%$ & 0.1 & $20.00 \%$ & 0.26 \\
\hline East Asian & $0.00 \%$ & 0.9 & $0.00 \%$ & 0.85 & $0.00 \%$ & 0.96 & $0.00 \%$ & 0.82 & $0.00 \%$ & 0.84 \\
\hline South Asian & $0.00 \%$ & 0.9 & $0.00 \%$ & 0.47 & $0.00 \%$ & 0.97 & $0.00 \%$ & 0.7 & $0.00 \%$ & 0.44 \\
\hline Others & $0.00 \%$ & 0.62 & $0.00 \%$ & 0.19 & $0.00 \%$ & 0.81 & $17.00 \%$ & 0.29 & $29.00 \%$ & 0.19 \\
\hline Total & $5.00 \%$ & 0.39 & $9.00 \%$ & 0.33 & $0.00 \%$ & 0.76 & $29.00 \%$ & 0.08 & $22.00 \%$ & 0.15 \\
\hline
\end{tabular}

The $\mathrm{I}^{2}$ and $P$ value were used to test the heterogeneity by the dominant model ( $T T+C T$ versus $\left.C C\right)$, recessive model (TT versus $\left.C C+C T\right)$, additive model $(C T$ versus $C C)$, additive model (TT versus $C$ ) and allele model (T versus $C)$, respectively

a

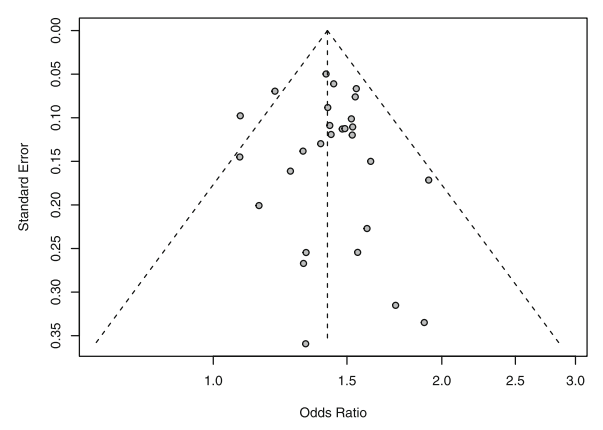

C

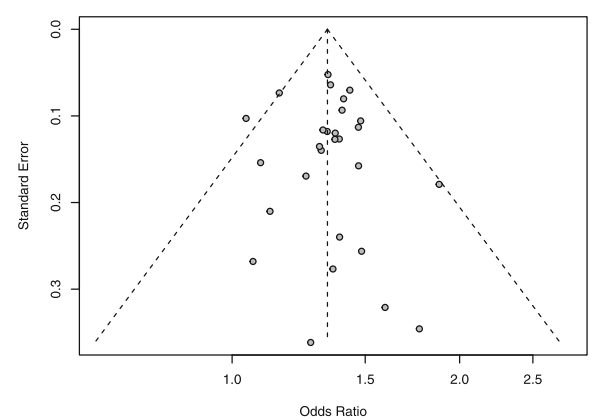

e

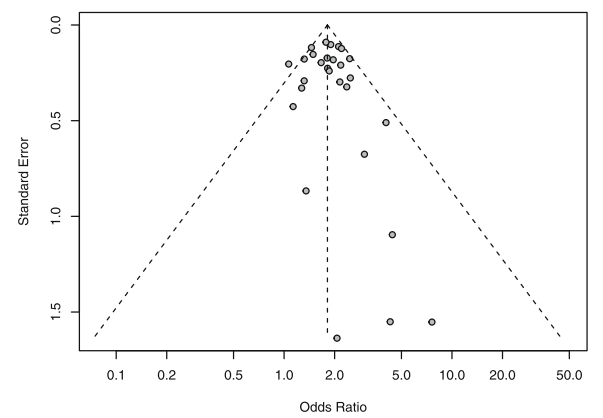

b

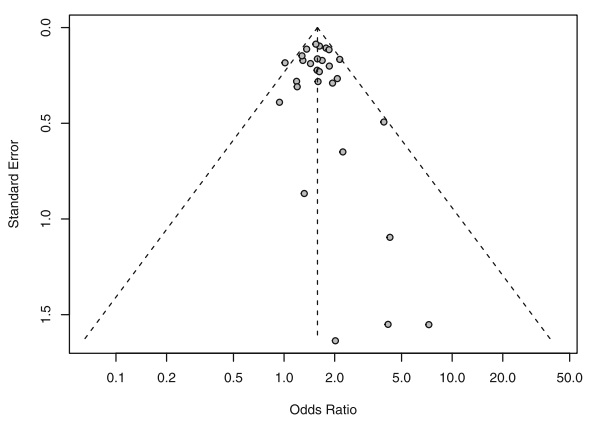

d

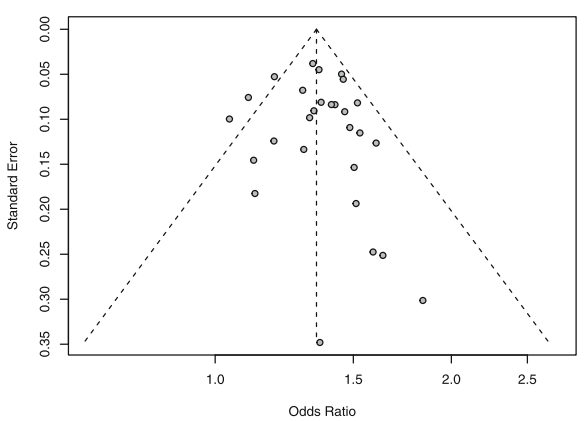

Fig. 2 The funnel plots of publication bias in different models. The funnel plots showed the results of the publication bias analyses between rs7903146 and T2DM by using a Dominant Model, b Recessive Model, c Additive Model (CT vs CC), d Allele Model and e Additive Model (TT vs CC). The Y-axis indicated the standard error of each study, and the standard error was smaller, the effect of the meta-analysis would be better 


\section{Heterogeneity test}

Odds Ratios and 95\% confidence intervals (CIs) were calculated to assess the association between rs7903146 and T2DM. The two quantities, Cochran's $Q$ and $\mathrm{I}^{2}$, were adopted to evaluate the heterogeneity in different kinds of ethnic groups. Q approximately follows a chi square distribution with $\mathrm{k}-1$ degrees of freedom (where $\mathrm{k}$ is the number of studies), and the $p$ value can be used to measure the significance level of the heterogeneity. The value of $\mathrm{I}^{2}$, ranging from 0 to $100 \%$, is calculated according to the formula, which is $\mathrm{I}^{2}=(\mathrm{Q}-(\mathrm{K}-1)) / \mathrm{Q}^{*} 100 \%$. The low, moderate, and high heterogeneity were labelled by $\mathrm{I}^{2}$ levels of $25 \%, 50 \%$ and $75 \%$, respectively. If $\mathrm{I}^{2}$ is less than $50 \%$, or $\mathrm{p}$ is more than 0.10 , the fixed effect model is used, otherwise the random effect model is adopted.

\section{Meta-analysis and subgroup analysis}

After the heterogeneity test, we used the $\mathrm{R}$ package meta to perform the experiment with the fixed effect model [53].

\section{Publication bias analysis and sensitivity analysis}

Begg's test [54] and Egger's test [55] were selected for testing the publication bias. When a two-tailed value is less than 0.05 , the publication bias is significant.

\section{Results}

\section{Literature search}

A flow diagram for the study selection process was shown in Fig. 1. A total of 355 articles were identified by the search strategy, abd 28 studies from 26 articles were left. The detailed information about

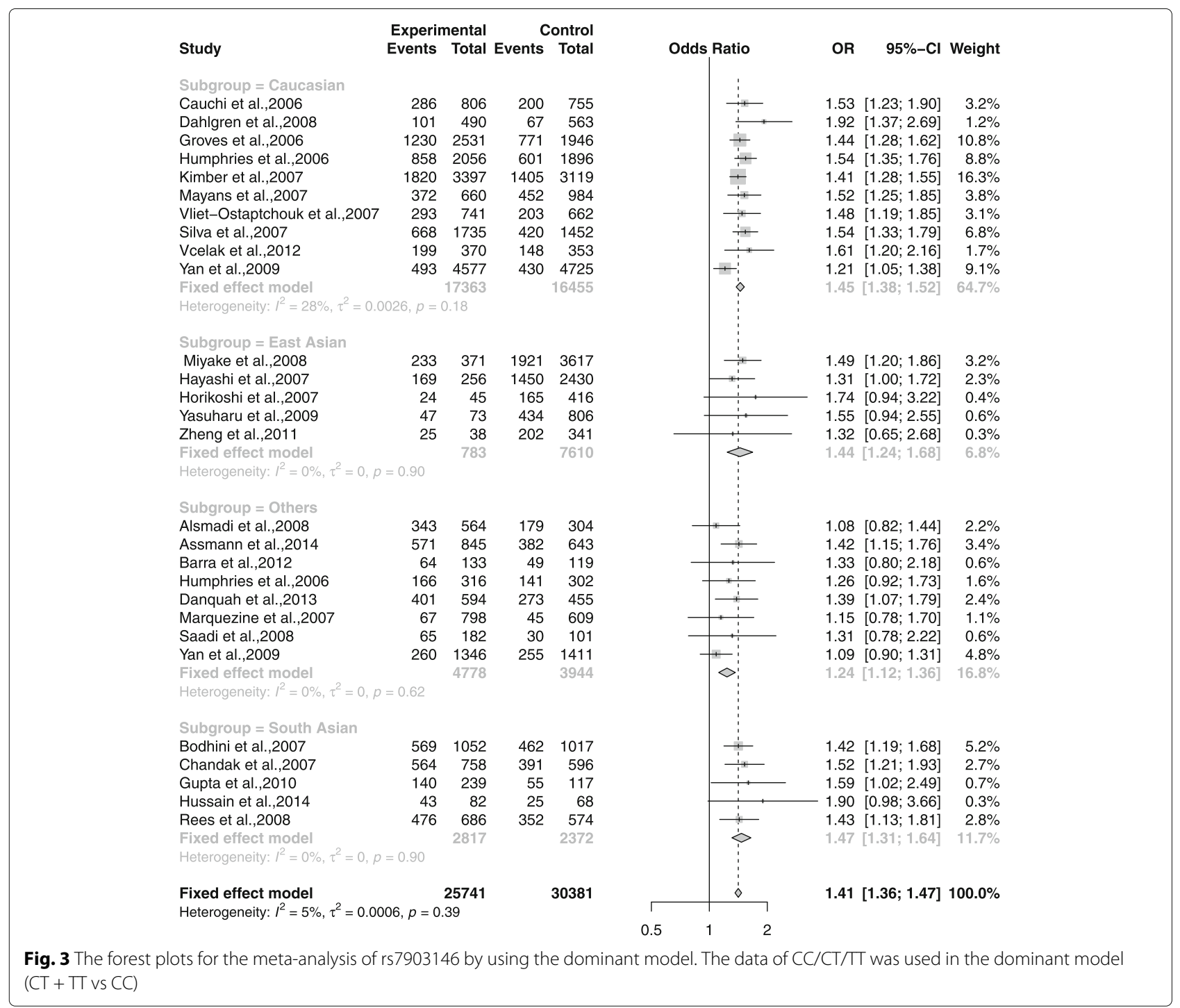


the search strategy was displayed in Additional file 1 : Table S1.

\section{Study characteristics}

As shown in Table 1, a total of 56628 participants (34232 cases and 22396 controls) of 28 studies from 26 articles were included in this meta-analysis. The studies were divided into Caucasian (10 studies) [4, 22, 29-36], East Asian (5 studies) [23, 25, 37-39], South Asian (5 studies) [42-46] and Others (Arab (2 studies) $[26,27]$, Black African (3 studies) [22, 28, 29] and Brazilian (3 studies) [24, 40, 41]) subgroups. The collected data, performed with the $\mathrm{R}$ package meta in this meta-analysis, was displayed in Additional file 1: Table S2.

\section{Heterogeneity test}

According to the genotypes shown in Table1, a total of 28 studies were analyzed by the dominant model, recessive model, additive model and allele model, respectively. The heterogeneity of all subgroups was shown in Table 2. According to the data displayed in Table 2, we didn't get the significant heterogeneity in the dominant model $\left(p=0.39\right.$ and $\left.\mathrm{I}^{2}=5.00 \%\right)$, recessive model $\left(p=0.33\right.$ and $\left.\mathrm{I}^{2}=9 \%\right)$, additive model (CT vs CC: $p=0.76$ and $\mathrm{I}^{2}=0.00 \%$ ), additive model (TT vs CC: $p=0.15$ and $\left.\mathrm{I}^{2}=22 \%\right)$ and allele model $\left(p=0.08\right.$ and $\left.\mathrm{I}^{2}=29 \%\right)$. As the $p$ value was more than 0.1 , we selected the fixed effect model.

\section{Publication bias analysis and sensitivity analysis}

The publication bias was not found in all models below. The $p$ values of Begg's test and Egger's test for the dominant, recessive, additive (CT vs CC), additive (TT vs CC) and allele model are 0.7821 and $0.7352,0.3635$ and $0.441,0.6354$ and 0.711 , 0.4528 and $0.5199,0.6927$ and 0.5673 , respectively. The

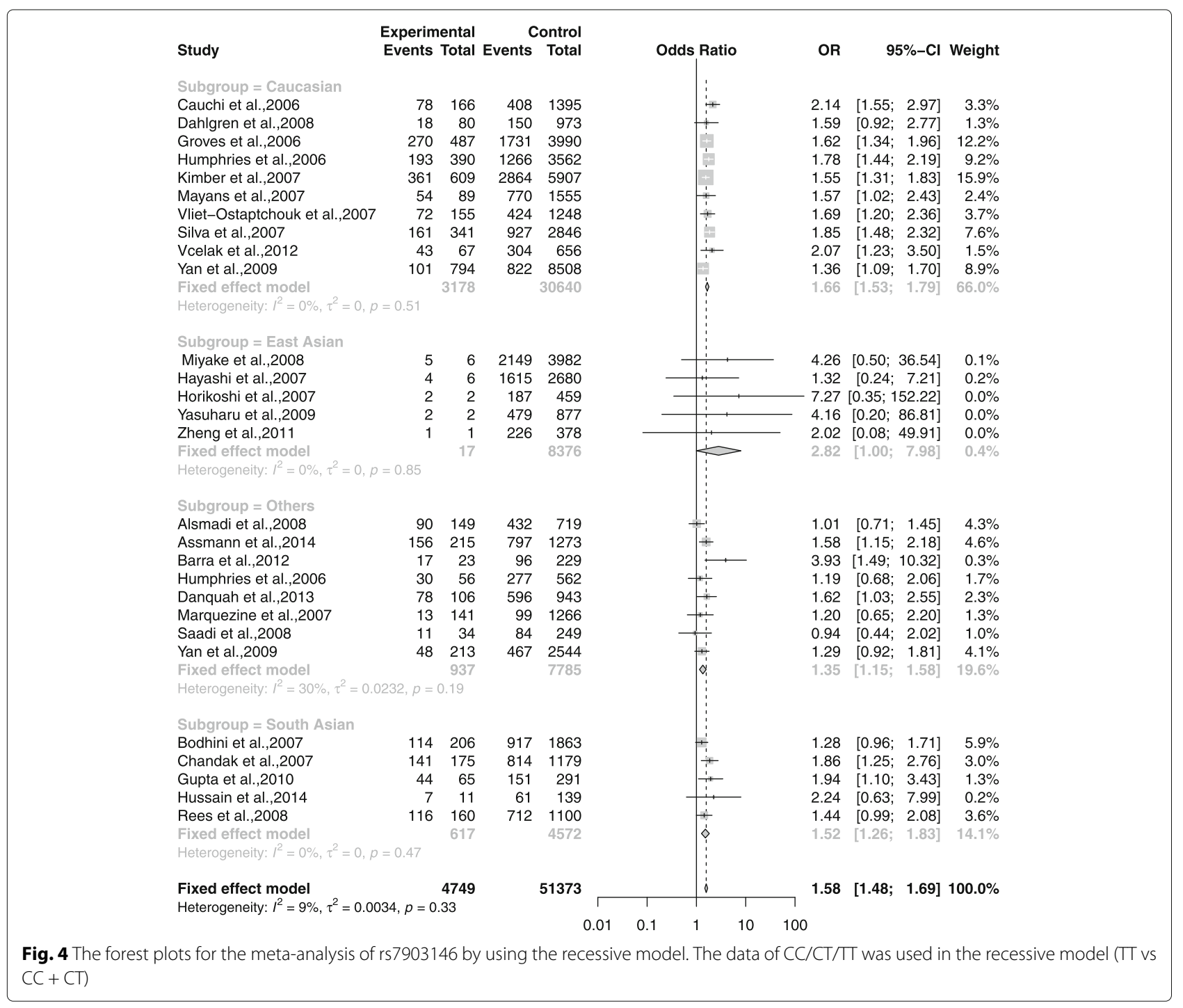


results were reflected in the funnel plots Fig. 2(a-e) directly.

\section{Association between rs7903146 and type 2 diabetes mellitus}

The association between rs7903146 and T2DM was shown in the forest plots: Figs. 3, 4, 5, 6 and 7 were the forest plots of the dominant model $(\mathrm{TT}+\mathrm{CT}$ versus $\mathrm{CC}$ ), recessive model (TT versus $\mathrm{CC}+\mathrm{CT}$ ), additive model (CT versus $\mathrm{CC}$ ), allele model ( $\mathrm{T}$ versus $\mathrm{C}$ ) and additive model(TT versus CC), respectively. We made the $\mathrm{Z}$ test, and the result was displayed in the Table 3.

In Caucasian subgroup, the results were shown as follows: dominant model (TT + CT vs $\mathrm{CC}):(\mathrm{OR}=1.45$, $\mathrm{CI}=1.38-1.52, p<0.0001$ ); recessive model (TT vs CC $+\mathrm{CT}):(\mathrm{OR}=1.66, \mathrm{CI}=1.53-1.79, p<0.0001)$; additive model $(\mathrm{CT}$ vs $\mathrm{CC}):(\mathrm{OR}=1.36, \mathrm{CI}=1.29-1.43, p<0.0001)$; additive $\operatorname{model}(\mathrm{TT}$ vs $\mathrm{CC}):(\mathrm{OR}=1.91, \mathrm{CI}=1.76-2.08)$, $p<0.0001)$; allele model ( $\mathrm{T}$ vs $\mathrm{C})$ : $(\mathrm{OR}=1.37, \mathrm{CI}=1.32$ $1.43, p<0.0001$ ).

In East Asian subgroup, the results were shown as follows: dominant model (TT $+\mathrm{CT}$ vs $\mathrm{CC}$ ): $(\mathrm{OR}=1.44, \quad \mathrm{CI}=1.24-1.68, \quad p<0.0001) ; \quad$ recessive model (TT vs $\mathrm{CC}+\mathrm{CT})$ : $(\mathrm{OR}=2.82, \mathrm{CI}=1.00-7.98$, $p=0.0509)$; additive model (CT vs $\mathrm{CC}):(\mathrm{OR}=1.42$, $\mathrm{CI}=1.21-1.65, \quad p<0.0001) ; \quad$ additive $\operatorname{model}(\mathrm{TT}$ vs $\mathrm{CC}):(\mathrm{OR}=1.81, \mathrm{CI}=1.69-1.94, \quad p<0.0001) ; \quad$ additive model (TT vs CC $)$ ( $(\mathrm{OR}=2.90, \mathrm{CI}=1.03-8.22, p=0.0446)$; allele model ( $\mathrm{T}$ vs $\mathrm{C}):(\mathrm{OR}=1.37, \mathrm{CI}=1.32-1.43$, $p<0.0001$ ).

In South Asian subgroup, the results were shown as follows: dominant model $(\mathrm{TT}+\mathrm{CT}$ vs $\mathrm{CC}):(\mathrm{OR}=1.41$, $\mathrm{CI}=1.31-1.64, p<0.0001)$; recessive model (TT vs CC $+\mathrm{CT}):(\mathrm{OR}=1.52, \mathrm{CI}=1.26-1.83, p<0.0001)$; additive model (CT vs $\mathrm{CC})$ : $(\mathrm{OR}=1.42, \mathrm{CI}=1.29-1.43$, $p<0.0001)$; additive model(TT vs $\mathrm{CC}):(\mathrm{OR}=1.81$,

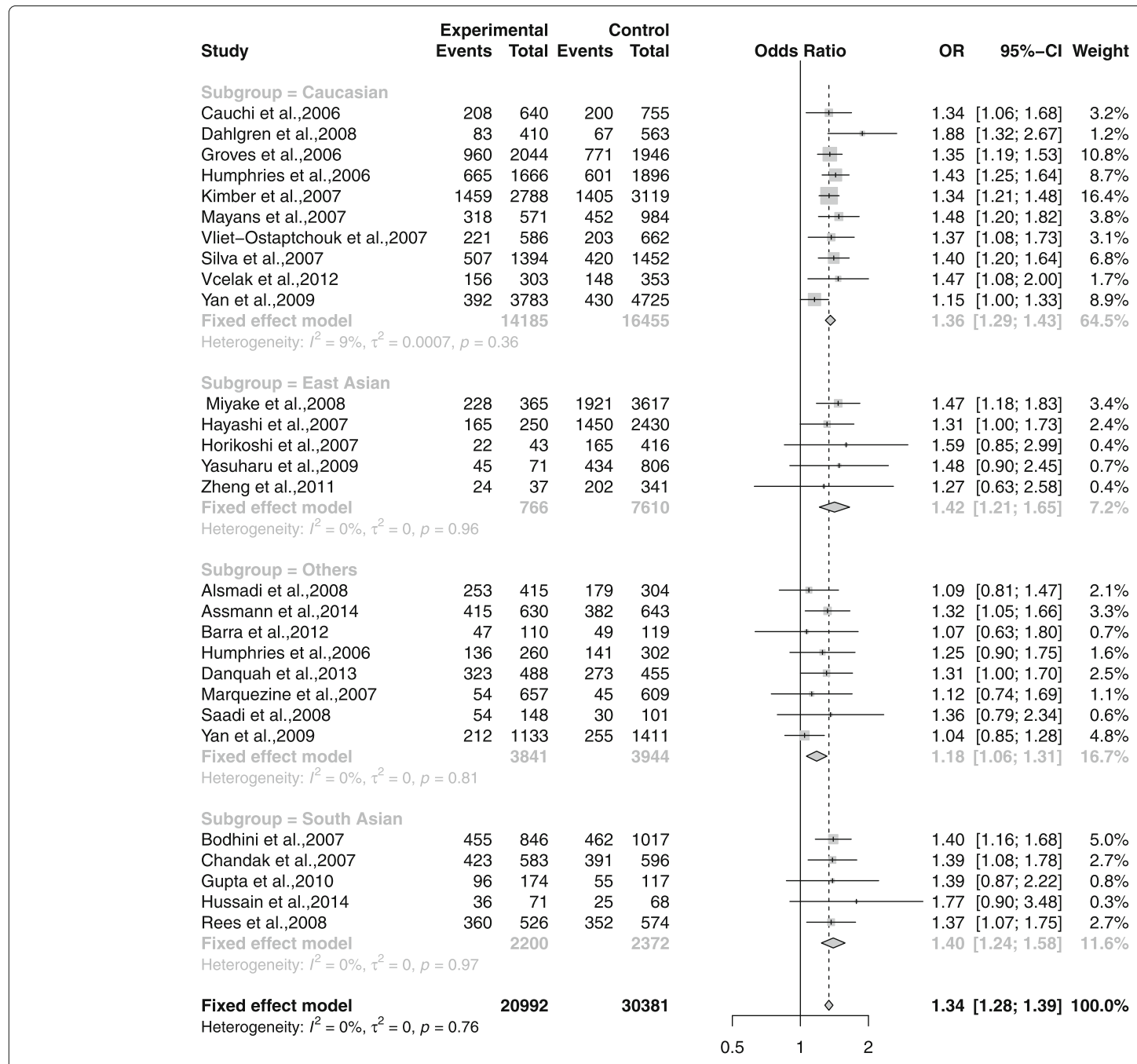

Fig. 5 The forest plots for the meta-analysis of rs7903146 by using the additive model. The data of CC/CT/TT was used in the additive model (CT vs CC) 


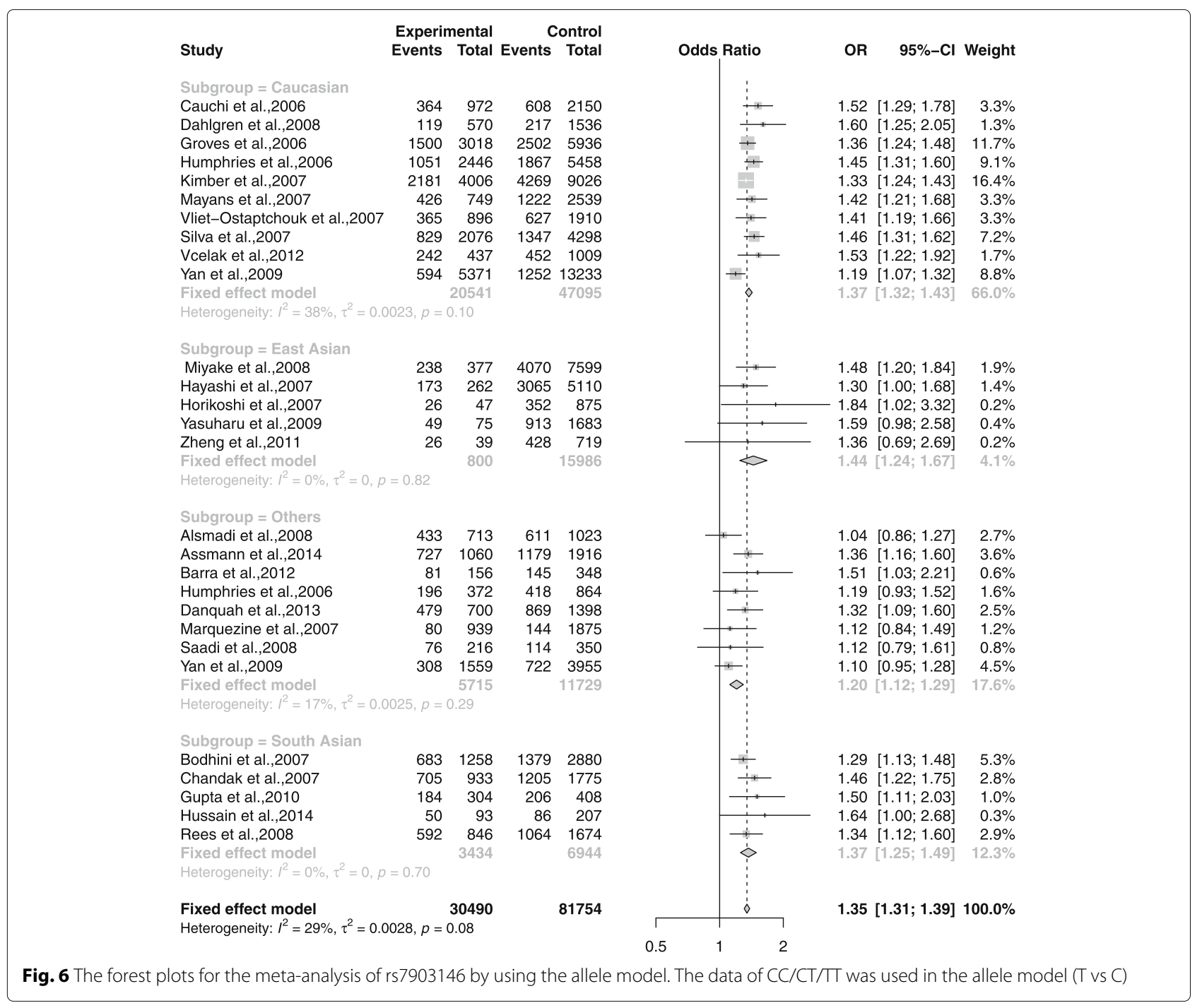

$\mathrm{CI}=1.69$ - 1.94, $p<0.0001)$; additive model(TT vs $\mathrm{CC}$ ): $(\mathrm{OR}=1.77, \mathrm{CI}=1.46-2.15, p<0.0001)$ allele model $(\mathrm{T}$ vs $\mathrm{C}):(\mathrm{OR}=1.44, \mathrm{CI}=1.24-1.67, p<0.0001)$.

In Others subgroup, the results were shown as follows: dominant model (TT $+\mathrm{CT}$ vs $\mathrm{CC})$ : $(\mathrm{OR}=1.24, \mathrm{CI}=1.12$ 1.36, $p<0.0001)$; recessive model (TT vs $\mathrm{CC}+\mathrm{CT}$ ): $(\mathrm{OR}=1.35, \mathrm{CI}=1.15-1.58, p=0.0002)$; additive model (CT vs $\mathrm{CC}): \quad(\mathrm{OR}=1.4, \quad \mathrm{CI}=1.24-1.58, \quad p=0.0019)$; additive model(TT vs $\mathrm{CC}):(\mathrm{OR}=1.48, \mathrm{CI}=1.26-1.75$, $p<0.0001)$; allele model ( $\mathrm{T}$ vs $\mathrm{C})$ : $(\mathrm{OR}=1.37, \mathrm{CI}=1.25$ $1.49, p<0.0001)$.

In total groups, the results were shown as follows: dominant model (TT $+\mathrm{CT}$ vs $\mathrm{CC})$ : $(\mathrm{OR}=1.41, \mathrm{CI}=1.36$ 1.47, $p<0.0001)$; recessive model (TT vs $\mathrm{CC}+\mathrm{CT}$ ): $(\mathrm{OR}=1.58, \mathrm{CI}=1.48-1.69, p<0.0001)$; additive model (CT vs CC $):(\mathrm{OR}=1.34, \quad \mathrm{CI}=1.28-1.39, \quad P<0.0001)$; additive model(TT vs $\mathrm{CC}):(\mathrm{OR}=1.81, \mathrm{CI}=1.69-1.94$, $p<0.0001)$; allele model ( $\mathrm{T}$ vs $\mathrm{C})$ : $(\mathrm{OR}=1.35, \mathrm{CI}=1.31$ $1.39, p<0.0001)$.

\section{Discussion}

In the meta-analysis, 56628 participants (34232 cases and 22396 controls) of 28 studies from 26 articles were included. The result of the four subgroups (Caucasian, East Asian, South Asian and Others) suggested that rs7903146 was significantly associated with T2DM in all subgroups and the total groups.

We removed each one of the studies in the groups or any subgroups in the dominant, recessive, additive and allele model for testing the robustness of results, respectively. The results did not change significantly, which displayed that the conclusion was robust. The heterogeneity and publication bias were not found in our meta-analysis.

We used the keywords "rs7903146", "type 2 diabetes" and "meta-analysis" to search in PubMed, and got nine articles [46, 56-63]. Our work was different from others. We analyzed the association between rs7903146 and T2DM in Caucasian, East Asian, South Asian and Others groups. We did not find a significant heterogeneity in all 


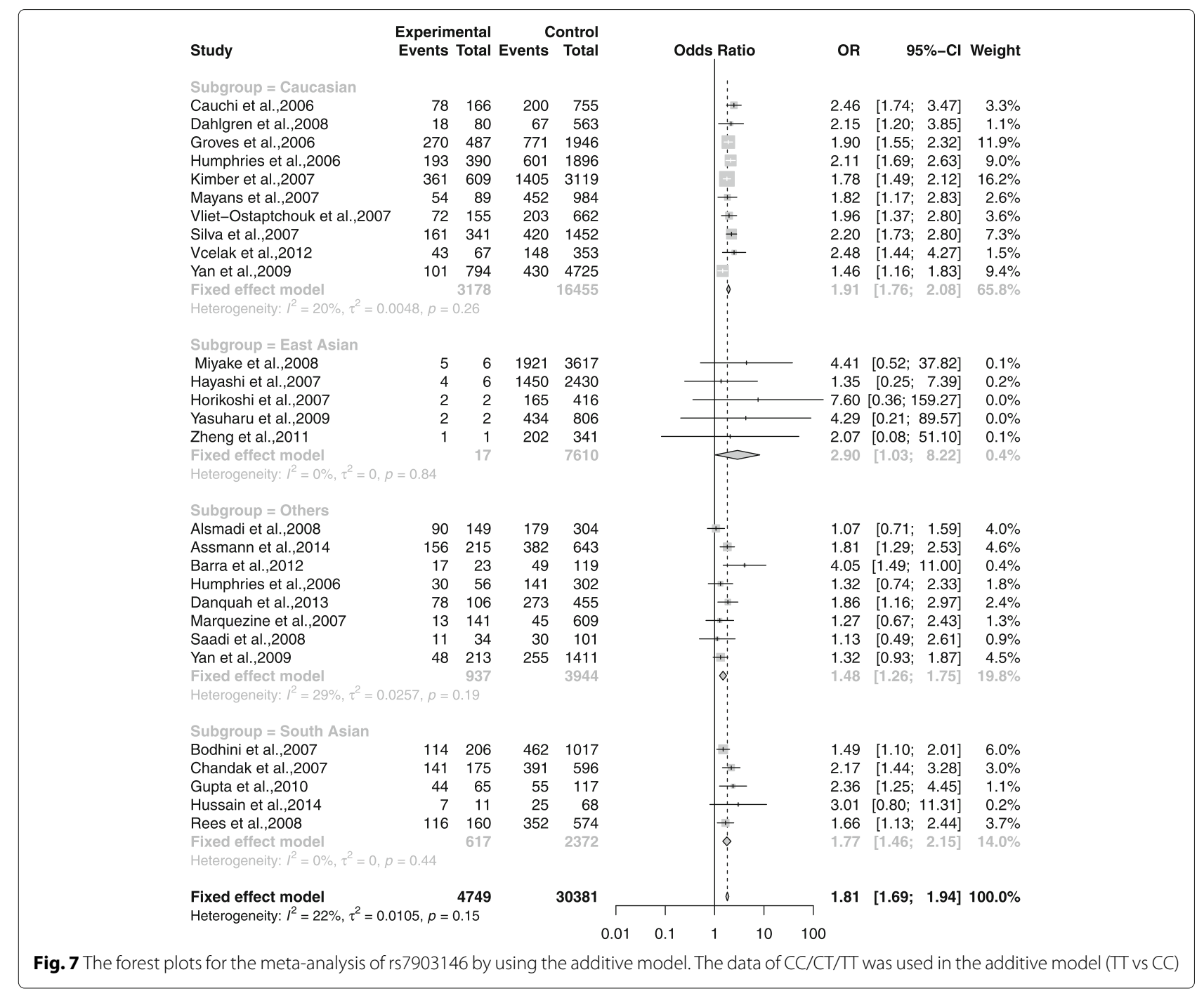

subgroup analyses, so the fixed effect model was used. We found that rs7903146 was associated with T2DM in Caucasian, East Asian, South Asian and other ethnicities significantly.

Some limitations existed in this meta-analysis. Firstly, considering the heterogeneity in all subgroup analyses, we excluded 9 articles. More articles should be added into the meta-analysis. Secondly, some of the same cases or controls may be used in different studies.

\section{Conclusion}

The meta-analysis suggested that rs7903146 was significantly associated with T2DM in Caucasian, East Asian, South Asian and other ethnicities.

Table 3 The result of the $Z$ test in subgroup analyses

\begin{tabular}{|c|c|c|c|c|c|c|c|c|c|c|}
\hline \multirow{2}{*}{ Subgroup } & \multicolumn{2}{|c|}{ Dominant } & \multicolumn{2}{|c|}{ Recessive } & \multicolumn{2}{|c|}{ Additive(CT vs CC) } & \multicolumn{2}{|l|}{ Allele } & \multicolumn{2}{|c|}{ Additive(TT vs CC) } \\
\hline & Z & $P$ & Z & $P$ & Z & $P$ & Z & $P$ & Z & $P$ \\
\hline Caucasian & 14.86 & $<0.0001$ & 12.35 & $<0.0001$ & 11.67 & $<0.0001$ & 16.98 & $<0.0001$ & 15.15 & $<0.0001$ \\
\hline South Asian & 4.69 & $<0.0001$ & 1.95 & 0.0509 & 4.42 & $<0.0001$ & 4.86 & $<0.0001$ & 2.01 & 0.0446 \\
\hline East Asian & 6.61 & $<0.0001$ & 4.47 & $<0.0001$ & 5.45 & $<0.0001$ & 7.12 & $<0.0001$ & 5.83 & $<0.0001$ \\
\hline Others & 4.17 & $<0.0001$ & 3.75 & 0.0002 & 3.11 & 0.0019 & 4.89 & $<0.0001$ & 4.65 & $<0.0001$ \\
\hline Total & 17.2 & $<0.0001$ & 13.53 & $<0.0001$ & 13.73 & $<0.0001$ & 19.38 & $<0.0001$ & 13.73 & $<0.0001$ \\
\hline
\end{tabular}

The $Z$ test was performed with the dominant model (TT+CT versus $C C$ ), recessive model (TT versus $C C+C T$ ), additive model $(C T$ versus $C C$ ), additive model $(T \pi$ versus $C C)$ and allele model ( $T$ versus $C$ ), respectively 


\section{Additional file}

Additional file 1: Table S1. The detailed information about the search strategy. Table S2. The collected data in the meta-analysis. (XLSX $13 \mathrm{~kb}$ )

\section{Abbreviations}

Cls: Confidence intervals; HWE: Hardy-Weinberg Equilibrium; ORs: Odds ratio; SNP: Single necluotide polymorphism; T2DM: Type 2 diabetes mellitus; TCF7L2: Transcription factor 7-like 2

\section{Acknowledgements}

The authors gratefully thanked the editors and reviewers to help improve the manuscript.

\section{Funding}

This work was supported by China Natural Science Foundation (Grant No. 11301110), Natural Science Foundation of Heilongjiang Province of China (Grant No. QC2015076, No. A2015001 and No. LC2016024), China Postdoctoral Science Foundation (Grant No. 2015 T80326 and No. 2013M541346), Heilongjiang Postdoctoral Fund (Grant No. LBH-TZ0504, No. LBH-Z13058 and No. LBH-Q13072), Open Project Program of Key Laboratory of Symbolic Computation and Knowledge Engineering of Ministry of Education of Jilin University (Grant No. 93K172016K16), Open Project of State Key Laboratory of Urban Water Resource and Environment of Harbin Institute of Technology (Grant No. ES201602) and National High-Tech Research and Development Program (863) of China (No: 2015AA020101, 2015AA020108, 2014AA021505).

\section{Availability of data and materials}

All the data generated or analyzed in this study was included in this manuscript.

\section{Authors' contributions}

WYD wrote the paper. SLJ and LX revised the paper. WYD, ZJH, LIZ and SLJ collected and selected the data, designed and performed the experiment. $\mathrm{QHJ}$ and ZW conducted the project. ZJH and SLJ helped interpret the results. WYD and LX developed analytical tools. All authors discussed the results and contributed to the final manuscript. All authors read and approved the final manuscript.

\section{Ethics approval and consent to participate \\ Not applicable.}

\section{Consent for publication}

Not applicable.

\section{Competing interests}

The authors declared that they had no competing interests.

\section{Publisher's Note}

Springer Nature remains neutral with regard to jurisdictional claims in published maps and institutional affiliations.

\section{Author details}

${ }^{1}$ College of Computer Science and Technology, Harbin Engineering University, No.145 Nantong Street, Nangang District, 150001 Harbin, China. ${ }^{2}$ School of Information Engineering, Yangzhou University, No.196, Huayang West Road, 225127 Yangzhou, China. ${ }^{3}$ School of Life Science and Technology, Harbin Institute of Technology, No.92 Xidazhi Street, Nangang District, 150001 Harbin China. ${ }^{4}$ Key Laboratory of Symbolic Computation and Knowledge Engineering of Ministry of Education, Jilin University, No.2699, Qianjin Avenue, Qianweinan District, 130012 Changchun, China. ${ }^{5}$ Department of Mathematics, Harbin Institute of Technology, No.92, Xidazhi Street, Nangang District, 150001 Harbin, China.

Received: 1 May 2017 Accepted: 23 February 2018

Published online: 07 March 2018

\section{References}

1. Cho NH, Whiting D, Forouhi N, Guariguata L, Hambleton I, Li R, Majeed A, Mbanya JC. Idf diabetes atlas. 7th edition. Brussels: International Diabetes Federation; 2015.

2. Yu X, Wang Y, Kristic J, Dong J, Chu X, Ge S, Wang H, Fang H, Gao Q, Liu D, et al. Profiling igg n-glycans as potential biomarker of chronological and biological ages: A community-based study in a han chinese population. Medicine. 2016:95(28)

3. Meng Q, Ge S, Yan W, Li R, Dou J, Wang H, Wang B, Ma Q, Zhou Y, Song M. Screening for potential serum-based proteomic biomarkers for human type 2 diabetes mellitus using maldi-tof ms PROTEOMICS-Clinical Applications. 2017;11(3-4)

4. Vcelak J, Vejrakova D, Vaňkova M, Lukasova P, Bradnova O, Halkova T, Bes?ak J, Andělova K, Kvasnickova H, Hoskovcova P, et al. T2d risk haplotypes of the tcf7l2 gene in the czech population sample: the association with free fatty acids composition. Physiol Psychol. 2012;61(3): 229.

5. Smith U. Tcf7/2 and type 2 diabetes - we wnt to know. Diabetologia. 2007;50(1):5-7.

6. Ross SE, Hemati N, Longo KA, Bennett CN, Lucas PC, Erickson RL, Macdougald OA. Inhibition of adipogenesis by wnt signaling. Science. 2000;289(5481):950-953.

7. Grant SF, Thorleifsson G, Reynisdottir I, Benediktsson R, Manolescu A, Sainz J, Helgason A, Stefansson H, Emilsson V, Helgadottir A, et al. Variant of transcription factor 7-like 2 (tcf7l2) gene confers risk of type 2 diabetes. Nat Genet. 2006;38(3):320-3.

8. Lyssenko V, Lupi R, Marchetti P, Guerra SD, Orhomelander M, Almgren $P$, Sjogren M, Ling C, Eriksson K, Lethagen S, et al. Mechanisms by which common variants in the tcf7l2 gene increase risk of type 2 diabetes. J Clin Investig. 2007;117(8):2155-63.

9. Osmark P, Hansson O, Jonsson AM, Ronn T, Groop L, Renstrom E. Unique splicing pattern of the tcf7l2 gene in human pancreatic islets. Diabetologia. 2009;52(5):850-4.

10. Orahilly S, Barroso I, Wareham NJ. Genetic factors in type 2 diabetes: The end of the beginning? Science. 2005;307(5708):370-3.

11. Manolopoulos VG, Ragia G, Tavridou A. Pharmacogenomics of oral antidiabetic medications: current data and pharmacoepigenomic perspective. Pharmacogenomics. 2011;12(8):1161-91.

12. Iordanidou M, Tavridou A, Petridis I, Arvanitidis KI, Christakidis D, Vargemezis $\mathrm{V}$, Manolopoulos VG. The serotonin transporter promoter polymorphism (5-httlpr) is associated with type 2 diabetes. Clinica Chimica Acta. 2010;411(3):167-71.

13. Ragia G, Petridis I, Tavridou A, Christakidis D, Manolopoulos VG. Presence of cyp2c9* 3 allele increases risk for hypoglycemia in type 2 diabetic patients treated with sulfonylureas. Pharmacogenomics. 2009;10(11):1781-87.

14. Ragia G, Tavridou A, Petridis I, Manolopoulos VG. Association of kenj11 e23k gene polymorphism with hypoglycemia in sulfonylurea-treated type 2 diabetic patients. Diabetes Res Clin Pract. 2012;98(1):119-24.

15. Zhao F, Mamatyusupu D, Wang Y, Fang H, Wang H, Gao Q, Dong H, Ge S, Yu X, Zhang J, et al. The uyghur population and genetic susceptibility to type 2 diabetes: potential role for variants in capn10, apm1 and fut6 genes. J Cell Mol Med. 2016;20(11):2138-47.

16. Adua E, Roberts P, Sakyi SA, Yeboah FA, Dompreh A, Frimpong K, Anto EO, Wang W. Profiling of cardio-metabolic risk factors and medication utilisation among type ii diabetes patients in ghana: a prospective cohort study. Clin Transl Med. 2017;6(1):32.

17. Altshuler D, Hirschhorn JN, Klannemark M, Lindgren CM, Vohl M, Nemesh J, Lane CR, Schaffner SF, Bolk S, Brewer C, et al. The common ppar|[gamma]| pro12ala polymorphism is associated with decreased risk of type 2 diabetes. Nat Genet. 2000;26(1):76-80.

18. Gloyn AL, Weedon MN, Owen KR, Turner MJ, Knight BA, Hitman G, Walker M, Levy JC, Sampson M, Halford S, et al. Large-scale association studies of variants in genes encoding the pancreatic $\beta$-cell katp channel subunits kir6. 2 (kcnj11) and sur1 (abcc8) confirm that the kcnj11 e23k variant is associated with type 2 diabetes. Diabetes. 2003;52(2):568-72.

19. Iordanidou M, Tavridou A, Vasiliadis MV, Arvanitidis KI, Petridis J, Christakidis D, Vargemezis V, Bougioukas G, Manolopoulos VG. The-759c/t polymorphism of the 5 -ht2c receptor is associated with type 2 diabetes in male and female caucasians. Pharmacogenet Genomics. 2008;18(2):153-9. 
20. Tavridou A, Petridis I, Vasileiadis M, Ragia G, Heliopoulos I, Vargemezis V, Manolopoulos VG. Association of vkorc1- $1639 \mathrm{~g} / \mathrm{a}$ polymorphism with carotid intima-media thickness in type 2 diabetes mellitus. Diabetes Res Clin Pract. 2011;94(2):236-41.

21. Cauchi S, Meyre D, Dina C, Choquet H, Samson C, Gallina S, Balkau B, Charpentier G, Pattou F, Stetsyuk V, et al. Transcription factor tcf7l2 genetic study in the french population. Diabetes. 2006;55(10):2903-8.

22. Yan $Y$, North KE, Ballantyne CM, Brancati FL, Chambless LE, Franceschini N, Heiss G, Kottgen A, Pankow JS, Selvin E, et al. Transcription factor 7-like 2 (tcf7l2) polymorphism and context-specific risk of type 2 diabetes in african american and caucasian adults the atherosclerosis risk in communities study. Diabetes. 2009;58(1):285-9.

23. Horikoshi M, Hara K, Ito C, Nagai R, Froguel P, Kadowaki T. A genetic variation of the transcription factor 7 -like 2 gene is associated with risk of type 2 diabetes in the japanese population. Diabetologia. 2007;50(4): 747-51.

24. Barra GB, Dutra LAS, Watanabe S, Costa PGG, Cruz PSMD, Azevedo MF, Amato AA. Association of the rs7903146 single nucleotide polymorphism at the transcription factor 7-like 2 (tcf7l2) locus with type 2 diabetes in brazilian subjects. Arq Bras Endocrinol E Metabologia. 2012;56(8): 479-84.

25. Zheng X, Ren W, Zhang S, Liu J, Li S, Li J, Yang P, He J, Su S, Li P. Association of type 2 diabetes susceptibility genes (tcf7l2, slc30a8, pcsk and pcsk2) and proinsulin conversion in a chinese population. Mol Biol Rep. 2011;39(1):17-23.

26. Saadi H, Nagelkerke N, Carruthers SG. Association of tcf7/2 polymorphism with diabetes mellitus, metabolic syndrome, and markers of beta cell function and insulin resistance in a population-based sample of emirati subjects. Diabetes Res Clin Pract. 2008;80(3):392-398.

27. Ezzidi I, Mtiraoui N, Cauchi S, Vaillant E, Dechaume A, Chaieb M, Kacem M, Almawi WY, Froguel P, Mahjoub T, et al. Contribution of type 2 diabetes associated loci in the arabic population from tunisia: a case-control study. BMC Med Genet. 2009;10(1):33-33.

28. Danquah I, Othmer T, Frank LK, Beduaddo G, Schulze MB, Mockenhaupt FP. The tcf7l2 rs7903146 (t) allele is associated with type 2 diabetes in urban ghana: a hospital-based case-control study. BMC Med Genet. 2013;14(1):96-96.

29. Humphries SE, Gable DR, Cooper JA, Ireland H, Stephens JW, Hurel SJ, Li KW, Palmen J, Miller MA, Cappuccio FP, et al. Common variants in the tcf7l2 gene and predisposition to type 2 diabetes in uk european whites, indian asians and afro-caribbean men and women. J Mol Med. 2006:84(12):1005-1014.

30. Groves CJ, Zeggini E, Minton JAL, Frayling TM, Weedon MN, Rayner NW, Hitman GA, Walker M, Wiltshire S, Hattersley AT, et al. Association analysis of 6,736 u.k. subjects provides replication and confirms tcf7l2 as a type 2 diabetes susceptibility gene with a substantial effect on individual risk. Diabetes. 2006:55(9):2640-44.

31. Cauchi S, Achhab YE, Choquet H, Dina C, Krempler F, Weitgasser R, Nejjari C, Patsch W, Chikri M, Meyre D, et al. Tcf7l2 is reproducibly associated with type 2 diabetes in various ethnic groups: a global meta-analysis. J Mol Med. 2007;85(7):777-82

32. Van Vlietostaptchouk JV, Shirisverdlov R, Zhernakova A, Strengman E, Van Haeften TW, Hofker MH, Wijmenga C. Association of variants of transcription factor 7-like 2 (tcf7/2) with susceptibility to type 2 diabetes in the dutch breda cohort. Diabetologia. 2007;50(1):59-62.

33. Mayans S, Lackovic K, Lindgren P, Ruikka K, Agren A, Eliasson M, Holmberg D. Tcf7l2 polymorphisms are associated with type 2 diabetes in northern sweden. Eur J Hum Genet. 2007;15(3):342-6.

34. Kimber $\mathrm{CH}$, Doney AS, Pearson ER, Mccarthy MI, Hattersley AT, Leese GP, Morris AD, Palmer CNA. Tcf7I2 in the go-darts study: evidence for a gene dose effect on both diabetes susceptibility and control of glucose levels. Diabetologia. 2007;50(6):1186-91.

35. De Silva NMG, Steele AM, Shields BM, Knight B, Parnell K, Weedon MN, Hattersley AT, Frayling TM. The transcription factor 7-like 2 (tcf7l2) gene is associated with type 2 diabetes in uk community-based cases, but the risk allele frequency is reduced compared with uk cases selected for genetic studies. Diabet Med. 2007;24(10):1067-72.

36. Dahlgren A, Zethelius B, Jensevik K., Syvänen A-C, Berne C. Variants of the tcf7l2 gene are associated with beta cell dysfunction and confer an increased risk of type 2 diabetes mellitus in the ulsam cohort of swedish elderly men. Diabetologia. 2007;50(9):1852.
37. Hayashi T, Iwamoto Y, Kaku K, Hirose H, Maeda S. Replication study for the association of tcf7l2 with susceptibility to type 2 diabetes in a japanese population. Diabetologia. 2007;50(5):980-4.

38. Miyake K, Horikawa Y, Hara K, Yasuda K, Osawa H, Furuta H, Hirota Y, Yamagata K, Hinokio Y, Oka Y, et al. Association of tcf7l2 polymorphisms with susceptibility to type 2 diabetes in 4,087 japanese subjects. J Hum Genet. 2007;53(2):174-180.

39. Tabara Y, Osawa H, Kawamoto R. Replication study of candidate genes associated with type 2 diabetes based on genome-wide screening. Diabetes. 2009;58(2):493-498.

40. Marquezine GF, Pereira AC, Sousa AB, Mill JG, Hueb W, Krieger JE. Tcf7l2 variant genotypes and type 2 diabetes risk in brazil: significant association, but not a significant tool for risk stratification in the general population. BMC Med Genet. 2008;9(1):106-106.

41. Assmann TS, Duarte GCK, Rheinheimer J, Cruz LA, Canani LH, Crispim D. The tcf7l2 rs7903146 (c/t) polymorphism is associated with risk to type 2 diabetes mellitus in southern-brazil. Arq Bras Endocrinol E Metabologia. 2014;58(9):918-25.

42. Chandak GR, Janipalli CS, Bhaskar S, Kulkarni SR, Mohankrishna P, Hattersley AT, Frayling TM, Yajnik CS. Common variants in the tcf7/2 gene are strongly associated with type 2 diabetes mellitus in the indian population. Diabetologia. 2007;50(1):63-67.

43. Bodhini D, Radha V, Dhar M, Narayani N, Mohan V. The rs $12255372(\mathrm{~g} / \mathrm{t}$ ) and $\mathrm{rs} 7903146(\mathrm{c} / \mathrm{t})$ polymorphisms of the $\mathrm{tcf} 7 \mathrm{I} 2$ gene are associated with type 2 diabetes mellitus in asian indians. Metab Clin Exp. 2007;56(9): $1174-8$.

44. Rees SD, Bellary S, Britten AC, Ohare JP, Kumar S, Barnett AH, Kelly MA. Common variants of the tcf7l 2 gene are associated with increased risk of type 2 diabetes mellitus in a uk-resident south asian population. BMC Med Genet. 2008;9(1):8-8.

45. Gupta V, Khadgawat R, Ng HKT, Kumar S, Aggarwal A, Rao VR, Sachdeva MP. A validation study of type 2 diabetes-related variants of the tcf7l2, hhex, kcnj11, and adipoq genes in one endogamous ethnic group of north india. Ann Hum Genet. 2010;74(4):361-8.

46. Hussain H, Ramachandran V, Ravi S. Tcf7l2 rs7903146 polymorphism and diabetic nephropathy association is not independent of type 2 diabetes - a study in a south indian population and meta-analysis. Endokrynologia Polska. 2014;65(4):298-305.

47. Guo SW, Thompson EA. Performing the exact test of hardy-weinberg proportion for multiple alleles. Biometrics. 1992361-372.

48. Han Z, Jiang Q, Zhang T, Wu X, Ma R, Wang J, Bai Y, Wang R, Tan R, Wang $Y$. Analyzing large-scale samples confirms the association between the rs 1051730 polymorphism and lung cancer susceptibility. Sci Rep. 2015;5:15642.

49. Yang $Y$, Wang W, Liu G, Yu Y, Liao M. Association of single nucleotide polymorphism rs3803662 with the risk of breast cancer. Sci Rep. 2016;6: 29008.

50. Little J, Higgins JP, loannidis JP, Moher D, Gagnon F, Von Elm E, Khoury MJ, Cohen B, Davey-Smith G, Grimshaw J, et al. Strengthening the reporting of genetic association studies (strega): an extension of the strobe statement. Hum Genet. 2009;125(2):131-51.

51. Lewis CM. Genetic association studies: design, analysis and interpretation Brief Bioinform. 2002;3(2):146-53.

52. Zhao F, Song M, Wang Y, Wang W. Genetic model. J Cell Mol Med. 2016;20(4):765-765.

53. Higgins JPT, Thompson SG, Deeks JJ, Altman DG. Measuring inconsistency in meta-analyses. BMJ. 2003;327(7414):557-60.

54. Begg CB, Mazumdar M. Operating characteristics of a rank correlation test for publication bias. Biometrics. 1994;50(4):1088-101.

55. Egger M, Smith GD, Schneider M, Minder CE. Bias in meta-analysis detected by a simple, graphical test. BMJ. 1997;315(7109): 629-34.

56. Guan Y, Yan L, Liu XY, Zhu X, Wang S, Chen L. Correlation of the tcf7/2 (rs7903146) polymorphism with an enhanced risk of type 2 diabetes mellitus: a meta-analysis. Genet Mol Res. 2016;15(3).

57. Peng S, Zhu Y, Lu B, Xu F, Li X, Lai M. Tcf7l2 gene polymorphisms and type 2 diabetes risk: a comprehensive and updated meta-analysis involving 121174 subjects. Mutagenesis. 2013;28(1):25-37.

58. Liu X, Xie CG, An Y, Zhang XX, Wu W. Meta-analysis of the association between the rs7903146 polymorphism at the tcf7l2 locus and type 2 diabetes mellitus susceptibility. Genet Mol Res. 2015;14(4):16856. 
59. Ding Y, Hu Z, Yuan S, Xie P, Liu Q. Association between transcription factor 7-like 2 rs7903146 polymorphism and diabetic retinopathy in type 2 diabetes mellitus: A meta-analysis. Diabetes Vasc Dis Res. 2015;12(6): 436-444.

60. Lin $Y$, Li $P$, Cai L, Zhang B, Tang $X$, Zhang $X$, Li Y, Xian Y, Yang $Y$, Wang $L$, et al. Association study of genetic variants in eight genes/loci with type 2 diabetes in a han chinese population. BMC Med Genet. 2010;11(1):97-97.

61. Dou $H, M a E$, Yin $L$, Jin $Y$, Wang $H$. The association between gene polymorphism of tcf 72 and type 2 diabetes in chinese han population: a meta-analysis. PLoS ONE. 2013;8(3).

62. Zhang B, Li W, Zhu M, Xu Y. Association of tcf7l2 gene polymorphisms with type 2 diabetes mellitus in han chinese population: a meta-analysis. Gene. 2013;512(1):76-81.

63. Wang J, Hu F, Feng T, Zhao J, Yin L, Li L, Wang Y, Wang Q, Hu D. Meta-analysis of associations between tcf7/2 polymorphisms and risk of type 2 diabetes mellitus in the chinese population. BMC Med Genet. 2013;14(1):8-8.

\section{Submit your next manuscript to BioMed Central and we will help you at every step:}

- We accept pre-submission inquiries

- Our selector tool helps you to find the most relevant journal

- We provide round the clock customer support

- Convenient online submission

- Thorough peer review

- Inclusion in PubMed and all major indexing services

- Maximum visibility for your research

Submit your manuscript at www.biomedcentral.com/submit 